\title{
KOMPETENSI PROFESIONAL GURU PENDIDIKAN AGAMA ISLAM (PAI) DI SEKOLAH UMUM TINGKAT SMA/ SMK KABUPATEN MAGELANG
}

\author{
Jaka Siswanta \\ Sekolah Tinggi Agama Islam Negeri (STAIN) Salatiga \\ jaksis71@yahoo.co.id.
}

\begin{abstract}
The problems on this research are: (1) How is the Islamic Religious Teacher characteristic of SMA/SMK in Magelang? (2) How is the professional competence of Islamic Religious Teacher of SMA/SMK in Magelang? (3) What factors influence the Islamic Religious Teacher professional competence of SMA/SMK in Magelang? This research was applying qualitative method by developing etno-methodology model. The subject of the research was Islamic Religious Teacher in 11 different SMA/ SMK. Observation and interview was applied to collect the data. The finding of the research showed that: 1) from 11 teachers, ten are graduated from Islamic teacher education and one from Syariah. They have more than ten year experiences in teaching. 2) They all have religious, social, and professional religious background. 3) The dominant factor influences their professional competence is on teaching experiences and motivation on doing their job.
\end{abstract}

Keywords: Profesional competence, Islamic Religious Teacher and Educational Chaacteristic

\begin{abstract}
Abstrak
Permasalahan dalam penelitian ini adalah: 1) Bagaiamanakah karakteristik kependidikan Guru PAI sekolah umum tingkat SMA/SMK di Kabupaten Magelang? (2) Bagaimanakab kompetensi profesional Guru PAI sekolah menengah umum tingkat SMA/SMK di Kabupaten Magelang? (3) Apakah faktor-faktor yang mempengarubi kompetensi profesional Guru PAI sekolah menengah umum tingkat SMA/SMK di Kabupaten Magelang? Pendekatan yang digunakan dalam penelitian ini adalab pendekatan kualitatif dengan mengembangkan model etnometodologi. Subyek penelitian adalah para guru PAI pada 11 SMA/SMK lokasi penelitian. Pengumpulan data dilakukan dengan pengamatan dan wawancara.
\end{abstract}


Temuan penelitian ini adalah 1) Karakteristik kependidikan guru PAI dari 11 informan, 10 orang berlatar belakang sarjana PAI dan seorang informan berlatar belakang pendidikan syari'ab. Pengalaman selurubnya lebib dari 10 tabun atau sebelum kebijakan KBK dan KTSP. (2) Kompetensi guru dibuktikan dengan dimilikinya kompetensi personal religius, sosial religius dan profesional religius (3) Faktor-faktor dominan yang mempengarubi kemampuan profesional guru agama terjadi dalam hal pengalaman kependidikan dan niat melaksanakan tugas.

Kata kunci: Kompetensi Profesional, Guru Pendidikan Agama Islam dan Karakteristik Kependidikan

\section{Pendahuluan}

Pendidikan Agama Islam (PAI) diharapkan menghasilkan manusia yang selalu berupaya menyempurnakan iman, takwa, dan akhlak, serta aktif membangun peradaban dan keharmonisan kehidupan, khususnya dalam memajukan peradaban bangsa yang bermartabat. Idealitas pendidikan agama di sekolah tersebut, dapat mencapai tujuan dengan baik apabila diemban oleh guru agama yang memiliki kemampuan profesional pada bidangnya. Dalam hal ini, guru agama memiliki tantangan yang cukup besar untuk melaksanakan tugas pembentukan kepribadian peserta didik. Globalisasi yang ditandai perkembangan ilmu pengetahuan dan teknologi dapat menggilas tatanilai sosial di tengah-tengah masyarakat.

Muchtar Buchori (1994:271) berasumsi bahwa praktek pendidikan agama di sekolah, baik sekolah-sekolah agama maupun sekolah-sekolah umum (SMA dan SMK) berlangsung secara menyendiri, kurang berinteraksi dengan kegiatan pendidikan lainnya. Selama ini belum dibiasakan adanya kerjasama interaktif penyelenggaraan pendidikan agama dengan kegiatan pendidikan sosial atau kemanusiaan, dalam rangka penanaman nilai dari keseluruhan nilai yang kompleks yang melandasi pengembangan ilmu pengetahuan dan teknologi.

Lebih ironis lagi, ketika idealitas penyelenggaraan pendidikan agama di sekolah cenderung tidak sejalan dengan kenyataan di lapangan. Dalam skala umum Fasli Jalal \& Dedi Supriadi (2001: 8) mengemukakan berbagai temuan penelitian bahwa mutu guru yang 
ditandai dari kepemilikan berbagai kompetensi masih menunjukkan keadaan yang memprihatinkan. Seperti misalnya, sebanyak 60\% guru madrasah (MI, MTs, dan MA) tidak memiliki kualifikasi yang memadai sebagai guru; sebanyak 20\% guru "salah kamar", yakni mengajar di luar bidang keahliannya, dan dari seluruh guru hanya $20 \%$ yang layak dari segi kualifikasi pendidikannya. Berbagai program peningkatan kualifikasi dan mutu guru, telah dilakukan kepada guru-guru SD/MI, SLTP/MTs, SLTA/MA melalui kegiatan yang mampu meningkatkan kualifikasi, pengetahuan dan kompetensi guru, namun belum terbukti pengaruhnya secara signifikan terhadap peningkatan hasil belajar siswa.

Temuan di atas memunculkan asumsi bahwa sebagian besar guru agama masih menghadapi persoalan yang berkaitan dengan kompetensi profesional yang dimilikinya. Oleh karena itu, permasalahan dalam penelitian ini dapat dirumuskan sebagai berikut: 1) Bagaimana karakteristik kependidikan guru PAI sekolah umum tingkat SMA/SMK di Kabupaten Magelang?; 2) Bagaimana keadaan kompetensi profesional guru PAI sekolah menengah umum tingkat SMA/SMK di Kabupaten Magelang?; 3) Apa faktor-faktor yang mempengaruhi kompetensi profesional guru PAI sekolah menengah umum tingkat SMA/SMK di Kabupaten Magelang?

\section{Kompetensi Guru PAI}

Kompetensi guru hakikatnya menunjuk pada suatu keadaan kemampuan yang dimiliki oleh guru dalam rangka melaksanakan tugas dan tanggung jawabnya dengan baik. W. Robert Houston dalam Roestiyah NK (1986: 68), memberikan definisi kompetensi "competence ordinarily is defined as adequancy for a task or as possessi on of requaire konwladge, skill and abilities" (suatu tugas yang memadai atau pemilikan pengetahuan, ketrampilan dan kemampuan yang dituntut oleh jabatan seseorang). Barlow (1985) dalam Raflis Kosasih (1999: 43), memberikan batasan kompetensi guru yakni "the ability of a teacher to responsibly perform his or her duties appropriately". Artinya, kompetensi guru merupakan kemampuan seorang guru dalam melaksanakan kewajiban-kewajibannya secara bertanggung jawab dan layak. 
Merujuk pendapat-pendapat di atas, dapat dipahami bahwa kompetensi guru mensyaratkan unsur kemampuan dan ketrampilan dalam pelaksanaan tugasnya. Dari sudut pandang pedagogie, Muhaimin dan Abdul Mudjib (1993: 19) mengemukakan bahwa seorang guru agama Islam harus memiliki kompetensi-kompetensi sebagai berikut:

1. Penguasaan materi Al-Islam yang komphrehensif serta wawasan dan bahan pengayaan, terutama pada bidang-bidang yang menjadi tugasnya.

2. Penguasaan strategi (mencakup pendekatan, metode dan teknik) pendidikan Islam termasuk kemampuan evaluasinya.

3. Penguasaan ilmu dan wawasan kependidikannya.

4. Memahami prinsip-prinsip dan kemampuan menafsirkan hasil penelitian pendidikan pada umumnya guna keperluan pengembangan PAI.

5. Memiliki kepekaan terhadap informasi secara langsung atau tidak langsung yang mendukung kepentingan tugasnya.

Dalam bagian lain, secara lebih spesifik dikemukakan tiga macam kompetensi yang harus dimiliki oleh guru agama Islam adalah sebagai berikut;

1. Kompetensi personal religius, yakni kompetensi yang menyangkut aspek kepribadian agamis seorang guru agama.

2. Kompetensi sosial-religius, yakni menyangkut kepedulian terhadap masalah-masalah sosial selaras dengan ajaran Islam.

3. Kemampuan profesional religius, yakni menyangkut kemampuan untuk menjalankan tugasnya secara profesional (Muhaimin dan Abdul Mudjib,1993: 22).

Saefuddin AM, (1990: 58) menjabarkan berbagai kompetensi yang secara praktis melekat pada seorang guru agama, yakni;

1. Kemampuan mengetahui hal-hal yang perlu diajarkan, sehingga ia harus belajar dan mencari informasi tentang materi yang diajarkan.

2. Menguasai keseluruhan materi yang akan disampaikan kepada anak. 
3. Mempunyai kemampuan menganalisis materi pelajaran yang diajarkan dan menghubungkannya dengan konteks komponenkomponen secara keseluruhan melalui pola yang diberikan secara Islam tentang bagaimana cara berpikir (way of thinking) dan cara hidup (way of life) yang dikembangkan dalam kegiatan belajara mengajar.

4. Mengamalkan informasi yang telah diperoleh sebelum disajikan kepada anak didik.

5. Mengevaluasi proses dan hasil pendididkan yang sedang dan telah dilaksanakan.

6. Memberi hadiah dan hukuman dengan upaya yang dicapai anak dalam rangka persuasi dan motivasi kepada anak didik.

7. Memberikan uswah hasanah dan meningkatkan kualitas den keprofesionalannya yang mengacu pada futuristik tanpa melupakan peningkatan kesejahteraan.

\section{Pengembangan Kemampuan profesional Guru PAI}

Munculnya istilah profesionalisme sebenarnya berawal dari asal kata profesi, yang dalam bahasa latin professio, yang berarti "pengakuan" atau "pernyataan". Menurut Muchtar Buchori (1994: 178), profesi berkaitan dengan pengakuan tentang bidang pekerjaan atau bidang pengabdian yang dipilih. Pengertian ini selanjutnya diarahkan melalui batasan-batasan tertentu sesuatu berkaitan dengan profesi. Pertama, profesi dikembangkan untuk memberikan pelayanan tertentu kepada masyarakat, baik secara individu maupun kelompok. Kedua, profesi bukan sekedar bidang pekerjaan atau mata pencaharian, melainkan di dalamnya terdapat unsur pengabdian kepada masyarakat melalui perangkat dan ketrampilan khusus. Ketiga, setiap profesi mempunyai kewajiban untuk menyempurnakan prosedur kerja yang mendasari pengabdiannya secara terus menerus.

Dalam aplikasinya, profesionalisme pada jabatan guru (agama) ditunjukkan dari sikap-sikap profesional dalam pelaksanaan tugas. Guru agama yang profesional hendaklah sebagai sosok yang kaya akan ilmu pengetahuan, memiliki kemampuan dalam bidang keguruan, memberikan pertolongan, bimbingan dan tauladan 
kepada anak didiknya, sehingga berhasil mencapai tujuan pendidikan Islam. Ahmad Tafsir (1991: 164), menegaskan bahwa jabatan profesional kependidikan Islam, yakni:

1. Profesi harus memiliki keahlian yang bersifat khusus.

2. Profesi harus diambil sebagai pemenuhan panggilan hidup atau panggilan atas pengabdiaannya kepada masyarakat.

3. Profesi memiliki teori-teori yang baku secara universal, yang berkaitan dengan keahlian sebagai tersebut di atas.

4. Profesi adalah untuk masyarakat sebagai alat pengabdian diri kepada masyarakat bukan untuk kepentingan diri pribadi, mengejar jabatan atau kedudukan.

5. Profesi harus dilengkapi dengan kecakapan dan kompetensi aplikatif.

6. Pemegang profesi memiliki otonomi dalam melakukan tugas profesinya.

7. Profesi hendaknya memilik kode etik.

8. Profesi hendaknya mempunyai klien yang jelas (peserta didik sebagai pemakai jasa profesi guru).

9. Profesi memerlukan organisasi profesi.

10. Profesi hendaknya mengenali hubungan antara profesinya dengan bidang-bidang lain.

Roestiyah (1986: 88), secara lebih operasional mengemukakan bahwa, kompetensi profesional guru ditunjukkan dengan kemampuan dalam melaksanakan berbagai tugas kependidikan, meliputi; mengajar, mendidik, dan melatih. Mengajar berorientasi pada kegiatan yang digunakan guru untuk men-trasfer atau menyampaikan ilmu pengetahuan dan informasi sebanyak-banyaknya sesuai petunjuk dan pedoman yang telah ditetapkan. Tugas mendidik, berorientasi pada kegiatan guru untuk memberi contoh dan tauladan yang baik, yang diterapkan kepada siswa melalui penenaman sikap dan perilaku yang baik (akblakul karimah) dalam kehidupan sehari-hari. Tugas melatih, berorientasi pada kegiatan yang dilakukan guru dalam membimbing, memberi contoh dan memberi petunjuk praktis yang berkaitan dengan gerakan, ucapan dan perbuatan lainnya dalam rangka pengembangan aspek psikomotorik yang ada dalam diri siswa. 
Ketiga tugas pokok jabatan profesional guru seperti tersebut di atas, sarat dimiliki oleh guru agama. Guru agama lebih memiliki tanggung jawab dalam menginternalisasi nilai dan tata nilai kehidupan melalui pelaksanaan tugas kependidikan. Oleh karena itu pelaksanaan tugas mendidik dan tugas melatih, di samping tugas mengajar, sangat mendukung guru dalam melaksanakan pembentukan watak dan kepribadian yang baik sesuai prinsipprinsip pendidikan Islam.

Peningkatan kompetensi profesional guru, termasuk guru agama merupakan suatu kebutuhan yang mendasar. Hal ini karena dapat sebagai bagian dari upaya meningkatkan mutu pendidikan, sementara keadaan mutu profesi guru belum sesuai dengan idealitas yang diharapkan. Upaya peningkatan dan pengembangan mutu profesi dapat dilakukan secara perorangan dan dapat pula dilakukan secara kelompok. Secara perorangan, peningkatan dan pengembangan mutu profesi guru dapat dilakukan secara formal dan dapat pula secara informal. Pengembangan secara formal dapat ditempuh dilembaga formal, sementara secara informal dapat ditempuh melalui informasi media, buku-buku terkait dan sebagainya.

\section{Metode Penelitian}

Fokus penelitian ini adalah kompetensi guru agama Islam. Oleh karena itu pendekatan yang dianggap cocok untuk kegiatan penelitian ini adalah pendekatan kualitatif. Lokasi penelitian dilakukan pada SMA/SMK baik negeri maupun swasta yang berada di wilayah Kabupaten Magelang. Subyek penelitian ini adalah guru PAI pada sekolah yang dipilih sebagai lokasi penelitian. Pengumpulan data dilakukan dengan teknik pengamatan dan wawancara. Analisis data dalam penelitian ini ditempuh secara induktif. Kegiatannya meliputi; reduksi data, penyajian data, dan penarikan kesimpulan (verifikasi). Reduksi data adalah proses pemilihan, pemusatan perhatian pada peyederhanaan atau transformasi data kasar yang muncul dari catatan-catatan tertulis di lapangan. Reduksi data dalam penelitian ini yaitu data yang dihasilkan dari pengamatan dan wawancara yang merupakan data yang masih mentah dan masih bersifat acakacakan serta komplek, oleh peneliti dilakukan penelitian data yang relevan dan bermakna untuk disajikan dengan cara memilih data 
yang mengarah pada pemecahan masalah dan memilih data yang mampu menjawab permasalahan penelitian, selanjutnya disederhanakan.

Penyajian data dilakukan dalam rangka pemahaman terhadap sekumpulan informasi yang terkumpul yang memberikan kemungkinan kepada adanya penarikan kesimpulan. Peneliti menyajikan data yang telah direduksi ke dalam laporan secara sistematik. Data disajikan dalam bentuk narasi mengenai kompetensi profesionalisme guru agama. Penarikan kesimpulan dilakukan secara bertahap untuk memperoleh kesimpulan akhir yang mempunyai derajat kepercayaan tinggi melalui metode induktif. Dengan demikian analisis data telah dilakukan semenjak awal pengambilan data atau informasi di lapangan.

\section{Deskripsi Subyek E Lokasi}

Penelitian tentang Kompetensi guru PAI di Sekolah Menengah Atas dan Sekolah Menengah Kejuruan di Kabupaten Magelang, menunjuk lokasi sekolah-sekolah Menengah Umum pada wilayah tersebut. Berdasar data penelitian, jumlah sekolah (SMA dan SMK) disebutkan bahwa terdapat sebanyak 33 Sekolah Menengah Atas, terdiri dari 10 SMA Negeri dan 23 SMA Swasta. Seluruh sekolah tersebut tersebar di 21 Kecamatan di wilayah Kabupaten Magelang. Untuk Sekolah Menengah Kejuruan terdapat dua SMK Negeri dan selebihnya Sekolah-Sekolah Swasta. Dua Sekolah Menengah Kejuruan berstatus Negeri adalah SMK Negeri Salam dan SMK Negeri Ngablak. Sekolah-Sekolah Menengah Kejuruan tersebut, lokasinya juga tersebar di wilayah-wilayah Kecamatan di Kabupaten Magelang.

Dari total jumlah Sekolah Menengah Atas dan Sekolah Menengah Kejuruan di Kabupaten Magelang, dipilih sebanyak 11 SMA/SMK. Sekolah-sekolah yang dipilih sebagai lokasi penelitian adalah sebagai berikut; (1) SMAN 1 Salaman, (2) SMAN Dukun, (3) SMAN 1 Kota Mungkid, (4) SMAN 1 Muntilan, (5) SMAN Candimulyo, (6) SMA Al Husain Salam, (7) SMA Sholikhin Bandongan, (8) SMAN Bandongan, (9) SMKN 1 Salam, (10) SMK Abdi Negara Muntilan, dan (11) SMK YPT Gulon, Salam. 
Karakteristik Kependidikan Guru PAI SMA/SMK di Kabupaten Magelang

Keadaan karakteristik kependidikan guru PAI dipaparkan melalui penentuan guru-guru yang dipilih sebagai informan dalam penelitian ini. Secara riil setiap guru nampak memiliki karakteristik yang berbeda-beda dalam hal latar belakang pendidikan dan pengalaman mengajar sebagai guru agama (PAI). Berdasar data penelitian diperoleh informasi mengenai keadaan informan penelitian, dengan identitias inisial sebagai berikut;

\section{Mnd}

Mnd adalah sosok guru PAI yang memiliki latar belakang pendidikan sarjana PAI IAIN Sunan Kalijaga Yogyakarta. Ia melaksanakan tugas mengajar pada mata pelajaran PAI sejak tahun 1984. Masa kerja sebagai guru yang telah berjalan selama kurang lebih 23 tahun itu, memberikan bekal yang cukup bagi dirinya dalam mengarungi dunia pendidikan khususnya pada mata pelajaran PAI.

Mnd merasakan Kurikulum PAI yang pertama ia kenal dalam kurikulum 1984. Perjalanan kurikulum berikutnya ia alami bersama lahirnya kebijakan kurikulum pendidikan tahun 1984. Pada perjalanan sepuluh tahun berikutnya terjadi perubahan kurikulum yang lazim disebut kurikulum 2004 dengan sebutan Kurikulum Berbasis Kompetensi (KBK). Hingga akhirnya masuk KTSP 2006.

Pada perubahan kurikulum terakhir Mnd merasa perlu pengenalan dan pemahaman yang serius agar KBK untuk pelajaran PAI dapat dilaksanakan dengan baik. Sosialisasi kurikulum ia ikuti, baik yang difasilitasi oleh Dinas Pendidikan Kabupaten Magelang, sosialisasi kurikulum di tingkat lokal sekolah maupun diskusi-diskusi dalam forum Musyawarah Guru Mata Pelajaran (MGMP) PAI. Perjalanan KBK belum sampai pada tataran operasional, munculah kebijakan baru berupa perubahan kurikulum disebut Kurikulum Tingkat Satuan Pendidikan (KTSP).

Meski sebagai guru yang disebut guru senior, ia merasa adanya permasalahan dalam memahami keberadaan kurikulum baru dalam format KTSP yang sekarang ini diberlakukan. Permasalahan itu ia rasakan dalam hal format pembelajaran yang harus 
dipersiapkan. Dengan format baru, tentunya perlu mempersiapkan format dengan substansi yang menurutnya masih substansi lama.

\section{Tqw}

Tqw adalah sosok guru mata pelajaran PAI di sebuah sekolah negeri di Kabupaten Magelang. Dalam perjalanan tugasnya sebagai guru, ia sempat mengalami tugas mengajar dalam kerangka pelaksanaan kurikulum pelajaran PAI, sejak kurikulum PAI 1975, selanjutnya memasuki kurikulum PAI 1984. Pada perubahanm kurikulum berikutnya, ia melaksanakan kebijakan kurikulum 2004, dan pada perkembangan kurikulum 2004 dalam format KBK ia masih aktif melaksanakan kegiatan pembelajaran. Memasuki prubahan kebijakan kurikulum dari KBK menuju KTSP 2006, ia pun sempat turut serta aktif memprakarsai pembahasan materi KTSP dalam forum Musyawarah Guru Mata Pelajaran PAI di Kabupaten Magelang.

Pengalaman kependidikan dalam bentuk mengajarkan materi pelajaran di kelas yang ia jalani kurang lebih tigapuluh tahunan itu, menjadikan ia sebagai guru yang sangat menguasai berbagai persoalan yang berkembang dalam praktek pembelajaran PAI. Oleh karenanya dalam pelaksanaan tugas mengajar ia merasa nyaman terkait dengan munculnya berbagai perubahan kebijakan dalam pendidikan seperti perubahan kurikulum yang telah berjalan berkali-kali.

\section{Nslm}

Nslm adalah seorang guru PAI, mengajar di sebuah Sekolah Menengah Atas Negeri di Kabupaten Magelang. Tugas mengajar yang ia laksanakan telah sesuai dengan latar belakang pendidikan yang ia miliki. Pengalaman mengajar yang ia jalani tergolong cukup lama, lebih dari duapuluh tahunan. Oleh karenanya, Nslm telah melaksanakan tugas mengampu mata pelajaran PAI, mulai dari perjalanan kurikulum 1984, selanjutnya terjadi perubahan kurikulum, yang muncul pada tahun 1994. Pada dekade sepuluh tahun kemudian, munculah kurikulum baru tahun 2004 dalam format Kurikulum Berbasis Kompetensi (KBK). Dan akhirnya, saat ini Nslm disibukan dengan realisasi/pelaksanaan KTSP untuk pelajaran PAI.

Nslm merasa tidak kesulitan dalam memahami substansi/isi dari setiap terjadinya perubahan kurikulum. Menurut Nslm, dalam 
setiap perubahan kurikulum hakikatnya substansi/isi dari materi kurikulum hampir sama. Perubahan terjadi dalam sekuen/penataan sistematika materi yang mengalami pergeseran. Nslm yang aktif dalam kegiatan MGMP PAI nampak tidak mengalami kesulitan yang berarti dalam memahami KTSP 2006 dalam mata pelajaran PAI. Ia menilai bahwa KTSP 2006 merupakan penyempurnaan dari KBK. Oleh karenanya, ia memahami bahwa materi dalam KTSP 2006 hakikatnya sama dengan materi dalam KBK 2004. Dengan demikian, persiapan ormat program tinggal menyesiaikan kemauan kurikulum yang ada.

4. Kmy

Kmy adalah sosok guru PAI di sekolah menengah atas berlokasi di daerah yang jauh dari keramaian kota. Jarak tempuh yang relatif jauh untuk mencapai lokasi tempat kerja tidak mengurangi semangatnya dalam melaksanakan tugas mengajar. Sebagai guru bidang studi PAI, ia amat terdukung oleh latar belakang pendidikan yang ia miliki yakni sarjana PAI.

Pengalaman mengajar yang ia jalani sebagai guru PAI telah berjalan lebih dari lima belas tahun. Praksis ia mengalami perjalanan sejarah kurikulum mulai dari kurikulum PAI tahun 1984, kurikulum PAI 1994, selanjutnya masuk pada kurikulum PAI 2004 dan ahirnya harus berhadapan dengan kurikulum pendidikan 2006 dalam format KTSP.

Pengalamannya dalam mengarungi berbagai materi kurikulum memberi kontribusi tersendiri dalam memahami setiap adanya perubahan kurikulum. Namun dalam memahami materi kurikulum Tingkat Satuan Pendidikan (KTSP) ia merasa amat kesulitan.

\section{Hsb}

Hsb sebagai sosok guru muda pada mata pelajaran PAI, dalam pelaksanaan tugas mengajar amat terdukung oleh latar belakang pendidikan yang ia miliki. Sarjana alumni Fakultas Tarbiyah pada program PAI IAIN Sunan Kalijaga Yogyakarta yang lulus pada tahun 1994 ini mulai bekerja sebagai guru PAI pada tahun 1997. Dengan demikian ia memiliki pengalaman mengajar kurang lebih 10 tahun. 
Perjalanan tugas mengajar yang ia laksanakan masuk dalam tiga wilayah kebijakan kurikulum PAI. Awal kali ia mengajar, kurikulum yang harus disampaikan adalah kurikulum PAI tahun 1994. Selanjutnya pada perubahan kurikulum yang terjadi pada 2004, ia juga terlibat aktif dalam memahami kurikulum tersebut yang lazim de kenal dengan Kurikulum Berbasis Kompetensi.

Perjalanan kurikulum berbasis kompetensi ini baru sekitar dua tahun, lahirlah kebijakan Kurikulum Tingkat Satuan Pendidikan (KTSP) 2006. Dalam posisi demikian Hsb, sangat berperan untuk berdiri pada barisan depan pada jajaran guru PAI di Kabupaten Magelang dalam mengawal perjalanan KTSP khususnya dalam forum MGMP PAI. Sebagai guru muda, ia mengaku memiliki komitmen untuk memajukan kualitas pembelajaran PAI.

Komitmen yang ia miliki itu, didukung aktivitasnya saat ini, dimana ia mendapat kepercayaan untuk mengikuti program studi lanjut di Program Pascasarjana Universitas Islam Negeri Sunan Kalijaga Yogyakarta pada Program Pendidikan Islam. Program Studi lanjut ini ia jalani atas dukungan dana pendidikan dari departemen agama RI.

6. $\mathrm{Knf}$

Knf adalah sosok tokoh muda dalam jajaran pengajar mata pelajaran PAI. Ia aktif mempelopori guru-guru lain dalam memahami setiap adanya perubahan kurikulum, terutama pada kurikulum 2004 dalam format KBK dan kurikulum 2006 dalam Format KTSP. Berbagai iven pertemuan nasional dalam kerangka sosialisasi program bari ia ikuti. Ia menjadi duta guru bagi guru-guru PAI khususnya yang berada di wilayah Kabupaten Magelang.

Dalam hal tugas mengajar PAI, ia merasa amat terdukung dengan latar belakang kependidikan yang ia miliki maupun kegiatan-kegiatan ilmian yang relevan dengan jabatannya sebagai guru PAI. Alumni Program PAI pada Fakultas Tarbiyah IAIN Sunan Kalijaga Yogyakarta ini tergolong dalam jajaran guru muda. Pengalaman kerja yang ia jalani belum genap duapuluh tahun. Namun, sepak terjang dalam kiprah bidang studi cukup menonjol.

Pada periode ini, Knf dipercaya oleh kesejawatan guru-guru PAI yang tergabung dalam forum MGMP PAI sebagai ketua. Posisi 
seperti ini, menyemangati Knf untuk selalu proaktif terhadap berbagai perubahan kebijakan dalam bidang kurikulum pendidikan.

\section{Asy}

Asy sebagai sosok pengajar PAI amat didukung dengan latar belakang pendidikan yang ia miliki, yakni sebagai sarjana PAI. Pengalaman mengajar dan latar belakang pendidikan yang ia miliki menguatkan pemahamannya terhadap materi pelajaran PAI. Perubahan kurikulum yang selama ini terjadi buka merupakan persoalan prinsip bagi Asy dalam mengemban misi pembelajaran PAI.

Asy yang memiliki pengalaman mengajar tidak kurang dari duapuluh tahun, telah mengalami praktek pengajaran mulai pada kurikulum PAI tahun 1984, kurikulum PAI tahun 1994, PAI dalam format KBK tahun 2004, dan akhirnya masuk wilayah pengajaran PAI dalam kurikulum tahun 2006.

Pada perjalanan KTSP, eksistensi Asy cukup mengambil peran dalam kerangka bersama-sama guru PAI yang lain memahami materi kurikulum tersebut. Dalam aspek isi/materi pelajaran PAI, yang dimuat dalam KTSP hakikatnya dipahami sama dengan materi dalam kurikulum-kurikulum sebelumnya.

8. Szh

Szh adalah sosok guru PAI yang mengampu di Sekolah Yayasan Islam di Kabupaten Magelang. Pelaksanaan tugas pembelajaran pada mata pelajaran PAI amat terdukung oleh berbagai faktor. Faktor yang berkait erat adalah latar belakang pendidikan yang ia miliki, yakni sebagai sarjana PAI, alumni fakultas Tarbiyah IAIN Sunan Kalijaga Yogyakarta.

Dalam perjalanan kerjanya sebagai guru, usia-usia kerja pada angkatan tersebut, ia termasuk personal guru yang inovatif dan kreatif. Semangat kerja muncul dan terlihat dari penampilan kerja yang ia lakukan secara serius. Prefesionalitas kerja nampaknya menjadi dasar bagi pelaksanaan amanah pekerjaan terutama dalam mengampu mata pelajaran PAI.

Berbagai cara dalam rangka pengembangan kompetensi ia lakukan, antara lain dengan melaksanakan studi lanjut pada jenjang pendidikan Magister, yang telah ia selesaikan pada awal 2006 lalu. 
Selain itu, ia berupaya untuk aktif dalam peranannya menggiatkan kegiatan MGMP khusus untuk guru-guru PAI.

9. St $\mathrm{Nj}$

$\mathrm{St} \mathrm{Nj}$ adalah sosok guru PAI yang telah mengalami pengabdian tugas sejak tahun 1984. Saat itu, ia mengajar di sebuah sekolah di Surakarta. Baru kemudian mulai awal 1987, ia melakukan mutasi, masuk ke sebuah sekolah menengah kejuruan Negeri di Kabupaten Magelang. Masa kerja kurang lebih 20 tahun yang dialami St $\mathrm{Nj}$ di sekolah tempat ia bekerja saat ini, dirasakan amat longgar. Dalam arti bahwa segala yang terkait dengan pelaksanaan tugas pembelajaran sesungguhnya amat dominan dipengaruhi kinerja dan etos kerjanya.

Meski demikian, St $\mathrm{Nj}$ merasakan bahwa keadaan pelaksanaan tugas yang selama ini dijalani tidak terlepas dari pengalaman kependidikan maupun pengalaman mengajar yang ia rasakan selama ini. Status kependidikan sarjana muda pada PAI cukup melandasi pemahamannya terhadap materi pelajaran. Namun, ia mengakui bahwa tatkala terjadi perubahan kurikulum, berbagai kesulitan awal muncul. Seperti halnya ketika dulu pelaksanaan kurikulum PAI 1984 telah berjalan, tiba-tiba hadir kurikulum 1994, dengan karakteristik yang sangat umum, kompleks, acuan materinya belum ada, ia amat merasakan kesulitan. Namun setelah berjalan akhirnya dapat dipahami dan dilaksanakan.

Pada perubahan berikutnya, muncul kurikulum PAI 2004 dalam format KBK, ia juga mengalami persoalan dalam hal memahami karakteristik kurikulum dengan berbagai aspeknya. Apalagi sejak hadirnya KBK, ia tidak terlibat dalam kegiatan MGMP PAI bersama guru-guru lain di tingkat SMA. Terakhir kali ia rasakan ketika muncul kurikulum PAI dalam format KTSP, juga dirasakan kesulitannya ketika memahami karakteristik kurikulum tersebut.

10. Bhd

Bhd adalah sosok guru PAI di sebuah SMK di wilayah Muntilan. Bhd sebagai sarjana Syari'ah IAIN Sunan Kalijogo Yogyakarta ini, awalnya bekerja sebagai Hakim pada Pengadilan Agama Kabupaten Magelang. Namun dalam sela-sela kesibukannya ia juga mengabdikan dirinya sebagai guru pada mata pelajaran PAI. 
Pengalaman mengajar sebagai guru PAI Bhd jalani dalam waktu yang cukup lama. Ia mengabdikan diri dalam tugas pembelajaran sejak masih berlakunya kurikulum PAI tahun 1975. Praksis bahwa ia mengalami sejarah perjalanan kurikulum PAI mulai dari kurikulum PAI 1975, Kurikulum PAI 1984, Kurikulum PAI 1994, Kurikulum PAI dalam format KBK 2006 dan terakhir kalinya Kurikulum PAI dalam format KTSP.

Pada perjalanan kurikulum 1994, ia seringkali terlibat dalam kegiatan MGMP PAI bersama-sama guru SMA. Namun begitu muncul kebijakan pemisahan MGMP antara guru-guru SMA sendiri, dan guru-guru SMK sendiri, kegiatan MGMP untuk kelompok guruguru SMK telah dua tahun terakhir ini tidak berjalan. Akibatnya ketika muncul perubahan kurikulum, ia merasa amat ketinggalan untuk memahami karakteristik kurikulum baru dimaksud.

\section{Msf}

Msf adalah guru PAI di sebuah SMK Swasta di wilayah Kabupaten Magelang. Posisinya sebagai guru PAI memang sejalan dengan latar belakang pendidikan yang ia miliki, yakni sebagai sarjana PAI. Ia tergolong guru muda dalam jajaran guru PAI di wilayah Kabupaten Magelang yang umumnya telah senior. Pengalaman mengajar sebagai guru Pendidikan Aghama Islam-pun belum genap sepuluh tahun, sehingga diriya baru terlibat dalam perjalanan kurikulum 1994 pada akhir masanya, kemudian disusul munculnya KBK 2004.

Sosialisasi terhadap pemahaman KBK 2004 dalam mata pelajaran PAI belum ia rasakan secara komphrehensif telah muncul kebijakan perubahan kurikulum dari KBK menjadi KTSP. Munculnya KTSP 2006 ini bagi Msf dirasakan sebagai kesulitan yang harus dihadap sebagai guru di sekolah. Apalagi, dalam jajaran guru SMK tidak ada kegiatan MGMP PAI, semakin menyulitkan dirinya untuk memahami esensi dan maksud dari kurikulum.

Msf akhirnya mengambil keputusan bahwa dalam pelaksanaan pembelajaran ia bersandar pada beredarnya buku-buku pelajaran yang ditulis dan diterbitkan. Ia menyampaikan materi sejalan dengan apa yang dikembangkan dalam buku PAI terbitan penerbit tertentu. Oleh karenanya, ia tidak melakukan interfensi materi atas paparan 
materi yang tertulis dalam buku tersebut. Keadaan itulah yang kemudian disampaikan kepada siswa dalam praktek pembelajaran.

\section{Analisis}

Pemahaman Guru terhadap Materi PAI dalam Kurikulum Tingkat Satuan Pendidikan (KTSP)

Pemahaman guru terhadap materi pelajaran PAI dalam KTSP menunjuk pada keadaan dimana guru menangkap esensi materi pelajaran dalam kurikulum tersebut. Munculnya kebijakan baru dalam pendidikan dalam bentuk lahirnya KTSP 2006 bukan tidak mungkin menyulitkan guru-guru, terutama dialami oleh guru yang bekerja secara sendirian. Dalam arti bahwa pelaksanaan pemahaman atas hadirnya kurikulum baru dilakukan secara personal melalui pemahaman buku-buku teks yang beredar, tanpa melakukan kajian secara perlahan/bertahap terhadap sosok kurikulum dimaksud.

Berdasarkan data penelitian, ditemukan berbagai keadaan pemahaman guru terhadap materi PAI dalam KTSP 2006. Pada kelompok pertama ditemukan keadaan di mana guru dengan mantab memahami materi PAI dalam cakupan KTSP 2006. Keadaan ini terjadi pada diri guru senior maupun guru-guru muda yang aktif tergaburng dalam forum MGMP PAI. Seperti yang terjadi pada Hsb bahwa ia benar-benar memahami esensi materi PAI dalam KTSP 2006. Pemahaman Hbs ini, juga senada dengan guru-guru lain yang nota bene aktif dalam kajian/diskusi materi PAI dalam Forum MGMP PAI. Guru-guru dimaksud seperti Mdn, Tqw, Nslm, Knf, Asy, dan Szh. Sedangkan untuk kelompok guru lain agaknya masih mengalami kesulitan dalam memahami esensi materi PAI dalam KTSP 2006.

Kmy mengakui mengalami kesulitan dalam memahami materi PAI yang termuat dalam KTSP 2006 oleh karena secara stuktur materi diubah dari struktur materi yang termuat dalam kurikulum sebelumnya. Hal yang dialami Kmy juga terjadi pada guru-guru yang lain, namun mereka tidak berkesempatan untuk terlibat dalam kegiatan MGMP, sehingga belum mendapatkan sosialisasinya. Seperti dialami Bhd, Kmy, Stnj, dan Msf, yang merasa belum mendapatkan sosialisasi ktsp di sekolahnya. 
Kejadian yang dialami oleh kelompok kedua ini memperlihatkan kurang/kesulitan memahami esensi materi PAI dalam KTSP 2006 karena mereka tidak terlibat aktif dalam diskusi-diskusi guru sejenis dalam kajian PAI kurikulum tersebut. Berbeda halnya kelompok guru lain yang amat memahami perubahan materi dalam kurikulum yang baru, oleh sebab saluran sosialisasi kebijakan baru dalam kurikulum pendidikan mereka dapatkan dalam berbagai forum diskusi di bawah payung MGMP PAI yang mereka adakan.

\section{Kompetensi Profesional Guru Agama SMA/SMK di Kabupaten Magelang}

Kompetensi profesional guru agama dapat diukur dari kompetensi personal religius, kompetensi sosial religius, dan kompetensi profesional religius.

\section{Kompetensi personal religius}

Temuan penelitian memperlihatkan bahwa para informan sebagai guru PAI di sekolah menunjukkan eksistensi kepribadian sebagai guru PAI yang memiliki kompetensi personal religius. Seperti pengakuan KMY saat dirinya memahami sebagai guru PAI merasa memiliki tanggungjawab moral terhadap kelakuan anak didiknya yang tidak disiplin dalam mengikuti pelajaran.

Nslm dan Asy lebih merasa terpanggil untuk menempatkan dirinya sebagai pengawal untuk menanamkan kepribadian muslim pada diri anak didiknya. Yang mereka lakukan di sekolah adalah meminta kebijakan sekolah untuk dilakukan tadarus al qur'an pada tiap pagi sebelum pelajaran dimulai, selanjutnya dilakukan kebijakan shalat berjamaah pada waktu dhuhur. Selain itu dilakukan pembinaan kegiatan-kegiatan ekstrakurikuler yang bertujuan pengembangan ketrampilan keagaamaan, seperti latihan Qiro'ah, kelompok pengajian remaja sekolah, pengajian rutin bulanan kelas, dan menggalakkan budaya berpakaian mulim bagi perempuan dengan mengenakan jilbab.

Beberapa kasus temuan di atas sesungguhnya memperlihatkan niat dan etos kerjanya sebagai guru PAI yang memiliki kemampuan personal religius. Keinginan mereka untuk mendidik, melatih dan menanamkan nilai-nilai kejujuran, kedisiplinan, ketekunan, 
dan nilai-nilai islami dalam diri peserta didik merupakan bagian yang tak terelakkan bahwa mereka dapat dikatakan sebagai guru yang memiliki kompetensi personal religius.

\section{Kompetensi sosial religius}

Kompetensi sosial religius menunjuk pada bagaimana guru PAI dapat memperlihatkan kepribadiannya yang mampu merespon masalah-masalah sosial yang selaras dengan ajaran Islam. Berdasarkan temuan data penelitian menunjukkan bahwa para informan memiliki kompetensi sosial religius. Seperti dialami Nslm, bahwa dirinya memikul tanggung jawab sosial sebagai manifestasi eksistensinya sebagai guru agama di sekolah. Ia dipercaya sebagai ketua pengurus yayasan masjid Nurul Iman di wilayah Kota Mungkid Kab. Magelang. Kesediaannya sebagai pengurus sekaligus pengisi berbagai kegiatan keagamaan di lingkungan masjid tersebut, ia yakini memberikan berkah hidup yang tiada tara. Pernah ia katakan rasa syukurnya ketika tanpa disangka mendapat kesempatan untuk menunaikan ibadah haji ke tanah suci dengan biaya yang tak terduga.

Hsb, sebagai guru PAI yang relatif lebih muda usia dari para guru lainnya mengambil peran sosial untuk mengawal pemahaman terhadap berbagai perubahan kebijakan pendidikan termasuk hadirnya KTSP di tengah-tengah tugas mengajar mereka. Ia yang sekaligus sebagai pengurus MGMP GPAI Kabupaten Magelang, selalu menyediakan diri untuk memprakarsai perlunya guru PAI memahami maksud dan kemauan kurikulum. Dalam forum MGMP ia selalu menempatkan diri untuk memandu para guru PAI yang tergabung dalam MGMP mempelajarai berbagai hal terkait dengan kebijakan KTSP, seperti telaah SI-SKL mapel PAI SMA/SMK, telaah SK-KD, bedah SKL, analisis kesulitan implementasi KTSP mapel PAI, pengembangan media, strategi dan pendekatan serta pengembangan instrumen evaluasi pembelajaran PAI SMA/SMK.

Sementara para guru lainnya seperti Mdn, Tqw, Kmy, Knf, Asy, Szh, StNj, Bhd maupun Msf, memperlihatkan kiprahnya di tengah-tengah masyarakatnya. Baik mereka berkiprah sebagai takmir masjid, sebagai pengurus kegiatan sosial di masyarakat maupun kegiatan-kegiatan lainnya. Mencermati berbagai kiprah sosial 
demikian dapat dipahami bahwa eksistensi guru PAI SMA/SMK di Kabupaten Magelang memiliki kompetensi sosial religius.

3. Kompetensi profesional religius

Kompetensi personal religius menunjuk pada diri guru yang mampu menjalankan tugasnya sebagai guru secara profesional. Tugas tersebut antara lain dalam kegiatan pengembangan materi pelajaran. Berdasarkan data penelitian terdapat kelompok guru yang sangat memahami esensi pengembangan materi pelajaran. Kelompok guru yang memiliki keadaan demikian terjadi dalam kelompok guru yang secara riil memahami esensi materi PAI dalam KTSP 2006.

Menurut pengakuan Mdn pengembangan materi pelajaran dalam pengajaran PAI mutlak dilakukan oleh setiap guru. Knf menguatkan Mdn bahwasannya setiap guru PAI harus mampu bekerja secara profesional. Tolok ukurnya ia tunjukkan lewat kemampuan memahami pengembangan materi pelajaran. Posisi guru dalam penyampaian materi tidak sekedar men-transfer dari paparan materi buku teks tetapi dapat meramu materi dengan mengacu SK dan KD yang dimuat dalam ketentuan. Pada kelompok guru lain yang kurang memahami esensi materi pelajaran cenderung kurang memahami esensi pengembangan materi pelajaran PAI. Keadaan ini dialami oleh Kmy, St Nj, Bhd maupun Msf.

Kelompok informan yang mampu mengembangkan materi pelajaran PAI terlihat pada penyusunan format pembelajaran yang selanjutnya dikembangkan ke dalam rencana operasional sampai pada pelaksanaan kegiatan pembelajaran di kelas. Seperti yang dialami Knf, pelaksanaan pengembangan materi dilakukan dengan cara menelaah SK- KD yang ada. Dari KD selanjutnya dijabarkan secara operasional kedalam indikator-indikator. Pengembangan materi pelajaran di lakukan dengan mengkaitkan berbagai aspek, terutama aspak-aspek yang terkait langsung dengan siswa sebagai sasaran pembelajaran. Kemampuan dalam mengembangkan materi pelajaran PAI seperti dialami Knf ini juga terjadi dalam diri guru pada kelompok yang secara esensi amat paham dengan materi PAI yang termuat dalam Kurikulum 2006.

Pada kelompok guru yang lain, mereka cenderung tidak melakukan pengembangan materi pelajaran. Aktivitas mereka pada 
kegiatan pembelajaran di kelas tidak lebih sekedar menyampaikan materi pelajaran sebagaimana uraiannya disebut dalam buku-buku tekks yang beredar di pasaran. Oleh karenanya mereka memposisikan sebagai pengguna hasil pengembangan materi yang dilakukan oleh penulis buku.

Faktor-faktor yang mempengarubi kompetensi profesional guru agama sekolab menengah umum tingkat SMA/SMK.

Faktor-faktor yang cukup terlihat mempengaruhi kompetensi profesional guru PAI di sekolah, adalah pengalaman kependidikan dan minat melaksanakan tugas. Pengalaman kependidikan dalam satu sisi cukup dirasakan sebagai salah satu faktor penunjang bagi kemampuan guru untuk melaksanakan pengembangan materi PAI. Seperti hasil temuan yang dilakukan kepada kolompok guru yang mampu mengembangkan materi PAI, mersa mengakui bahwa kemampuan mereka selama ini tidak terlepas dari pengalaman kependidikan yang ia miliki.

Melalui pengalaman kependidikan yang dialami dalam perjalanan kurikulum-kurikulum sebelumnya, akan bermanfaat sebagai pengalaman banding untuk memahami keadaan mata pelajaran PAI dalam kurikulum terakhir. Seperti yang dikemukakan Tqw, bahwasannya ketika kurikulum PAI yang dilaksanakan pada tahun 1994 sampai 2004, pengembangan materi dilakukan mulai dari penyususnan program pembelajaran. Komponen yang ada dalam format program saat itu tentu jauh berbeda dengan komponen format program yang terdapat dalam KBK maupun KTSP. Namun karena Tqw memiliki pengalaman dalam mengembangkan materi PAI kurikulum lama, maka ketika harus mengambangkan materi kurikulum baru untuk pelejaran PAI ia merasakan tak ada masalah.

Keadaan yang dialami oleh Tqw ini juga dirasakan oleh guruguru seperti Mnd, Nslm, Hsb, Knf, Asy dan Szh. Sedangkan untuk kelompok guru lain merasa bahwa ia belum mampu berkiprah secara maksimal dalam pembelajaran PAI, terutama dalam kegiatan pengembangan materi pelajaran. Mereka cenderung bersifat konservatif, dalam arti mempertahankan keadaan lama dalam kebijakan baru. Realisasinya, semestinya guru melakukan kegiatan pengembangan materi dari pedoman yang ada, faktanya mereka menggunakan 
penjabaran materi pelajaran yang dilakukan oleh orang lain.

Keadaan minat guru dalam melaksanakan tugas pembelajaran PAI di kelas juga amat bervariasi. Sebagian guru cenderung memiliki minat yang kuat untuk melaksanakan tugas pembelajaran PAI di kelas. Munculnya minat yang kuat ini tidak lepas dari dukungan kemampuannya dalam mengembangakan materi pelajaran. Menurut pengakuan Asy, dalam dirinya ada dorongan yang kuat agar dirinya melaksanakan tugas kependidikan secara profesional. Konsekwensi logis yang harus ia terima adalah banyaknya kegiatan yang harus dilakukan dalam kerangka pelaksanaan pembelajaran., seperti menyiapkan format program pembelajaran, melakukan berbagai inovasi cara mengajar, strategi pembelajarn yang dipilih harus bervariasi, cara evaluasi yang dikembangkan juga tidak monoton, dan sebagainya. Keadaan yang dialami oleh Asy hampir terjadi pada guru-guru yang potensinya dalam pengembangan materi pelajaran muncul. Pada guruguru lain yang sejak awal kurang memahami esensi materi pelajaran PAI nampaknya tidak termasuk dalam kelompok Asy.

Guru-guru yang tidak mampu mengembangkan materi PAI cenderung enggan untuk mengusik aktivitas tersebut. Sekali lagi, mereka lebih memilih untuk menyampaikan materi dari paparan materi yang telah tercantum dalam buku-buku teks yang beredar di pasaran.

\section{Kesimpulan}

Karakteristik kependidikan guru agama ditandai dari kepemilikan pendidikan dan pengalaman mengajar. Mayoritas guru memiliki latar belakang pendidikan yang sesuai untuk mengajar pelajaran PAI. Sedangkan, pengalaman mengajar yang dimiliki oleh para guru cenderung bervariasi. Kemampuan profesional guru agama dibuktikan dengan kemampuannya dalam melaksanakan tugas pembelajaran. Mayoritas guru terlihat memiliki kemampuan profesional dalam pelaksanaan tugas pembelajaran PAI, diperlihatkan pelaksanaan pengembangan materi dalam pelaksanaan pembelajaran. Sedangkan sebagian guru mengalami kesulitan dalam pengembangan materi sehingga kurang profesional sebagai guru agama.

Faktor-faktor dominan yang mempengaruhi kemampuan profesional guru agama terjadi dalam hal pengalaman kependidikan 
dan niat melaksanakan tugas. Pengalaman kependidikan ditandai dari aktivitas akademik, seperti pertemuan guru-guru mata pelajaran sejenis dalam forum MGMP, keikutsertaan dalam forum-forum ilmiah, seperti seminar, lokakarya dan sebagainya. Sedangkan, niat melaksanakan tugas ditandai dari kemauannya untuk mempersiapkan diri dalam pelaksanaan tugas pembelajaran.

\section{Daftar Pustaka}

AM , Saefuddin. 1990. Desekularisasi Pemikiran Landasan Islami. Bandung: Mizan.

Buchori , Muchtar. 1994. Spektrum Problematika Pendidikan Di Indonesia. Yogyakarta: Tiara Wacana.

1994. Penelitian Pendidikan dan Pendidikan Islam di Indonesia, Jakarta: IKIP Muhammadiyah Press.

DePorter, Bobbi et.All. 2001. Quantum Teaching, Mempraktekkan Quantum Learning di Ruang-ruang Kelas. Alih bahasa Ari Nilandari. Bandung: Penerbit Kaifa.

Moleong , Lexy J. 1988. Metodologi Penelitian Kualitatif. Jakarta: Ditjen Dikti P2LPTK.

Muhadjir, Noeng. 1996. Metodologi Penelitian Kualitatif. Yogyakarta: Rake Sarasin.

Muhaimin \& Abdul Mudjib. 1993. Pemikiran Pendidikan Islam, Kajian Filosofis dan Kerangka Dasar Operasionalisasinya. Bandung: Tragedi Karya.

Nasution. 1988. Metode Penelitian Kualitatif Naturalistik. Bandung: Tarsito.

NK, Rostiyah. 1986. Masalab-Masalah Ilmu Keguruan. Jakarta: Bina Aksara.

Popham, James \& Evi L. Baker. 1992. Teknik Mengajar Secara Sistematis. Jakarta: Rineka Cipta.

Soetjipto dan Raflis Kosasih. 1999. Profesi Keguruan. Jakarta: Rineka Cipta.

Syaifuddin N \& Basyaruddin U. 2002. Guru Profesional dan Implementasi Kurikulum, Jakarta: Ciputat Press.

Tafsir, Ahmad. 1991. Ilmu Pendidikan Dalam Perspektif Islam. Bandung: Rosda Karya.

Zaini, Hisyam dkk. 2002. Strategi Pembelajaran Aktif di Perguruan Tinggi, Yogyakarta: CTSD 